\title{
Use of Transtracheal Oxygen following Decannulation
}

\section{of Pediatric Tracheostomy}

Ujjwal Kumar Chowdhury*, Ramesh Menon, Niwin George, Lakshmi Kumari Sankhyan, Nikhil Bansal, Srikant Sharma, Diplomate , Suryalok Angadi, Vishwas Malik,

Cardiothoracic Sciences Centre All India Institute of Medical Sciences, New Delhi, India.

*Corresponding author: Ujjwal Kumar Chowdhury, Department of Cardiothoracic and Vascular Surgery AIIMS, New Delhi-110029, INDIA

Received date: September 22, 2020; Accepted date: October 30, 2020; Published date: November 04, 2020

Citation: Ujjwal K. Chowdhury., Ramesh Menon, Niwin George, Lakshmi K. Sankhyan., (2020) Use of Transtracheal Oxygen following Decannulation of Pediatric Tracheostomy. J, Clinical Cardiology and Cardiovascular Interventions, 3(10); Doi:10.31579/2641-0419/085

Copyright: (C) 2020 Ujjwal Kumar Chowdhury, This is an open access article distributed under the Creative Commons Attribution License, which permits unrestricted use, distribution, and reproduction in any medium, provided the original work is properly cited.

\begin{abstract}
Purpose: Uninterrupted sustained oxygenation is paramount in neonates and infants with cyanotic/acyanotic congenital heart diseases (CHD) undergoing closed or open heart surgeries and tracheostomy tube decannulation to avoid hypoxic events.

Description: We describe here-in a new device, permitting uninterrupted delivery of oxygen through the tracheostomy stoma, allowing continuation of enteral feeds and suctioning of the endotracheal secretions through the tracheostomy stoma.

Evaluation: Eighty-four neonates and infants with a median age of four months (IQR:23 days-9 months) undergoing different closed and open heart surgeries for cyanotic/acyanotic CHD with or without pulmonary arterial hypertension were treated with a device permitting uninterrupted oxygenation following tracheostomy tube decannulation. There were $11(13.1 \%)$ deaths due to multifactorial etiologies, and one was lost to follow-up. Seventy-two children were successfully decannulated using this protocol. At a median follow-up of 166(IQR:82.5-216) months, the actuarial survival was $86.61 \%$ (SE $\pm 0.04 \%$; 95\% CI: 77.1-92.3).

Conclusions: Transtracheal oxygenation through the tracheostomy stoma via a thin catheter allows uninterrupted oxygenation following tracheostomy tube decannulation, continuation of enteral feeds, and allows intermittent endotracheal suctioning, thus avoiding post decannulation hypoxic events.

Keywords: congenital heart disease; Congestive heart failure; tracheostomy; decannulation of tracheostomy tube, transtracheal oxygenation; tracheobronchomalacia.

Running title: Transtracheal oxygenation
\end{abstract}

\section{Introduction}

Despite advances in pediatric anaesthesia, intensive care and myocardial protection during the past decade, mortality attributed to pediatric tracheostomy ranges from 0.5 to $5 \%$ with European and American reviews.[1-3]

Decannulation as soon as the child's condition permit is always desirable to avert the extubation-reintubation cycle, mediastinitis, tracheostomy site breakdown, peristomal granulation, suprastomal granuloma, tracheitis, subglottic stenosis, tracheobronchomalacia, tracheobrachiocephalic artery fistula, and tracheoesophageal fistula. [1-3] Acute decannulation failures can be catastrophic and this risk should be minimized. Literature documents decannulation failure rates between $6.5 \%$ to $21.4 \%$. [1-7]

Over the past 23 years, we encountered a series of 84 neonates and infants requiring tracheostomy for prolonged mechanical ventilation and other causes. The leading causative factors for extubation failure and requirement of tracheostomy were cardiac cachexia (46.4\%), severe cardiac-related pulmonary arterial hypertension (46.4\%), unstable hemodynamics $(41.6 \%)$, persistent pulmonary infection, lung collapse and sepsis $(22.6 \%)$, renal failure requiring peritoneal dialysis and hemodialysis $(20.2 \%)$ and craniofacial syndromes with upper airway problems (19\%). Maintenance of sustained oxygenation post- decannulation is paramount to avoid hypoxic adverse events in these critically ill infants (Tables 1-3). [4]

In order to avert post-decannulation hypoxia, the corresponding author has developed a technique of supplementation of oxygen through the tracheostomy stoma with the aim of maintaining uninterrupted oxygenation for a varying period ranging between 1-5 days. In this report, we examined the effects of dual source of sustained oxygenation (transtracheostomy and oxygen hood) following decannulation of the tracheostomy tube to avert decannulation failure and hypoxic adverse events in these neonates and infants with cardiac cachexia and cyanotic/acyanotic congenital heart diseases (CHD) and pulmonary hypertension.

\section{Technical Considerations}

This study conforms to the principles outlined in the declaration of Helsinki and was approved by the Institutional Ethics Committee. Patients were enrolled in the study after obtaining informed consent from parents/guardians. The demographic characteristics of all 84 neonates and infants are presented in (tables $\mathbf{1}$ and 2). 
Decisions for extubation, reintubation, tracheostomy, and decannulation were made collectively by a panel of reviewers comprising of the cardiac intensivist, cardiac surgeon, respiratory therapist and otolaryngologist.

Between January 1997 and December 2019, the corresponding author have performed tracheostomy on 84 neonates and infants undergoing different types of closed and open heart surgical procedures (primary operation).

Tracheostomy was performed in the operating room using a midline vertical incision through the second to fourth tracheal cartilages in all patients. Utmost precautions were taken to avoid injury to the cricoid cartilage, esophagus and recurrent laryngeal nerve. The tube was not sutured to the skin. We minimized the pretracheal and paratracheal dissection between deep and superficial fascia and injury to the pleura to avoid the potentially lethal complications like tension pneumothorax and pneumomediastinum.

Decannulation was considered when patients had: i) no requirement of ventilator support for a period of 7 days; ii) minimal requirement for endotracheal suctioning; iii) no pulmonary atelectasis/lobar collapse; iv) stable hemodynamics with reduced/nil requirement of inotropes; v) no diaphragmatic paresis/paralysis; vi) normal kidney function; vii) patent upper airway, ascertained with laryngoscopy; viii) removal of any obstructing suprastomal granulation tissue; and ix) no comorbidities necessitating tracheostomy.

Our decannulation protocol contained the following: tracheostomy size reduction, and clinical observation, complete airway evaluation (flexible laryngoscopy, and direct tracheostomy and bronchoscopy), and intermittent non-invasive ventilation. The "capping trial" i.e. progressive downsizing of the tracheostomy tube followed by blocking of the tube stoma for extended periods of time, although practiced in adults, is difficult and risky in neonates and infants, hence was not practiced in our center.

The child's tracheostomy tube was down-sized to the smallest uncuffed tube (smallest $3 \mathrm{~mm}$ ) whenever possible. The lumen of a $2.5 \mathrm{~mm}$ tracheostomy tube is too small and there is difficulty in suctioning in the event of mucous plugging.

After proper suctioning of the posterior nasopharynx, suprastomal area, tracheobronchial tree, and preoxygenation, the tracheostomy tube was removed. A thin silastic catheter was inserted through the tracheostomy stoma for administering oxygen in an uninterrupted manner (Figure 1).

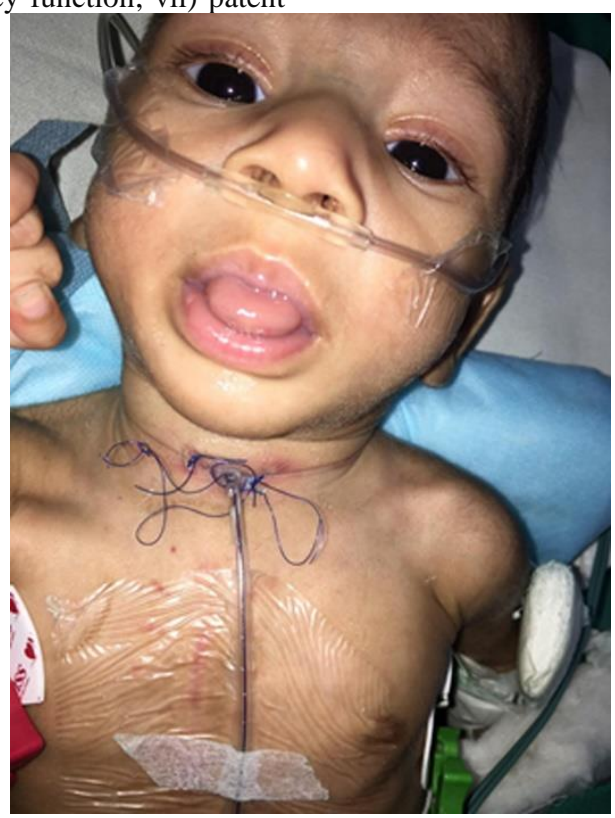

Figure 1: Photograph of the child who underwent reimplantation of anomalous origin of the left coronary artery from pulmonary artery with transtracheal oxygen through the tracheostomy stoma following decanulation of the tracheostomy tube. Note the dual source of oxygenation through the nasal prongs and tracheostomy stoma.

The infants head was placed in oxygen hood, thus providing dual source of oxygen for a period ranging between 1-5 days. During this period, the enteral feed was continued, and intermittent endotracheal suction was given through the tracheostomy stoma until peristomal edema subsided and natural non-obstructive airway was restored.

\section{Results}

\section{Original cohort}

The median age of patients at operation was 4months (IQR: 23days-9 months). Twenty-five (29.8\%) patients were younger than 1 month, and 59 (70.2\%) were between 1 and 12 months.

Thirty $(35.7 \%)$ infants in this study group were premature and thirty-nine $(46.4 \%)$ weighed less than $50^{\text {th }}$ percentile of predicted weight by national standards (Tables 1 and 2). 


\begin{tabular}{|c|c|}
\hline Variables & Number $(\%)$ \\
\hline $\begin{array}{cc}\text { Number of infants } \\
-\quad \leq 1 \text { month } \\
-\quad>1 \text { month }\end{array}$ & $\begin{array}{l}25(29.8 \%) \\
59(70.2 \%)\end{array}$ \\
\hline Age at operation (days) & 5-132 days \\
\hline Gestational age (weeks) & $36.2(29.7-37)$ \\
\hline Prematurity $<37$ weeks & $30(35.7 \%)$ \\
\hline Sex - Male & $50(59.5 \%)$ \\
\hline Birth weight $(\mathrm{kg})$, mean $\pm \mathrm{SD}$ & $\begin{array}{c}6.56 \pm 3.17 \text { (range, } 1.8-12 ; \text { median, } \\
7.6 \text { ) }\end{array}$ \\
\hline Low birth weight & $39(46.4 \%)$ \\
\hline Preoperative ventilation (days) & $29(34.5 \%)$ \\
\hline Genetic syndromes & $10(11.9 \%)$ \\
\hline Preoperative lung infection/lobar collapse & $19(22.6 \%)$ \\
\hline Upper airway problems & $16(19 \%)$ \\
\hline Unstable hemodynamics (on preoperative inotropes & $39(46.4 \%)$ \\
\hline Non-cardiac comorbidities & $6(7.7 \%)$ \\
\hline Preoperative central neurological event & $5(5.9 \%)$ \\
\hline Preoperative sepsis & $19(22.6 \%)$ \\
\hline Unilateral diaphragmatic paralysis & $7(8.3 \%)$ \\
\hline 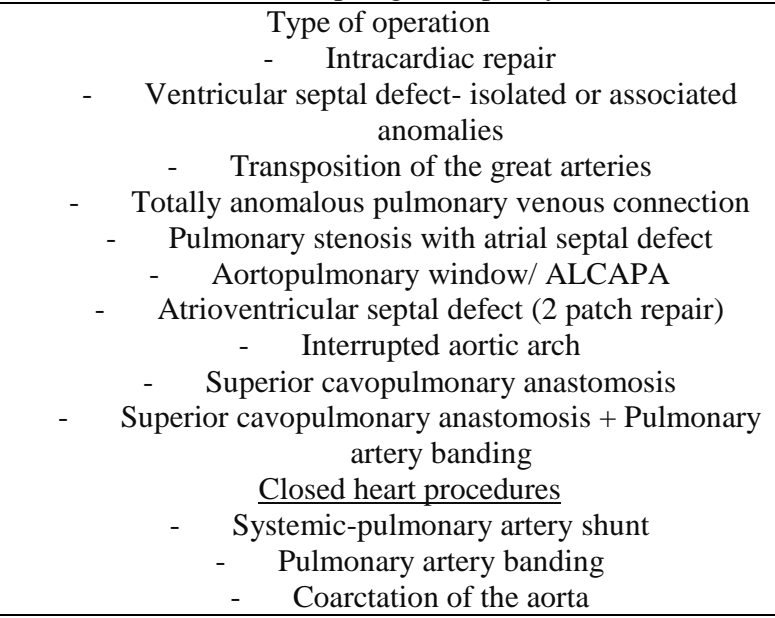 & $\begin{array}{c}7 \\
9 \\
11 \\
18 \\
1 \\
3 \\
2 \\
1 \\
7 \\
3 \\
\\
9 \\
10 \\
2\end{array}$ \\
\hline $\begin{array}{l}\text { Total number of days intubated and ventilated prior to } \\
\text { tracheostomy }\end{array}$ & 7 days- 26 days \\
\hline Duration of ventilation after tracheostomy & 14 days-69 days \\
\hline Successful decannulation & $73(86.9 \%)$ \\
\hline Post tracheostomy cumulative mortality & $11(13.1 \%)$ \\
\hline Cardiopulmonary bypass time (minutes), mean \pm SD (range) & $102.26 \pm 28.46(76-118)$ \\
\hline Aortic cross-clamp time (minutes), mean \pm SD (range) & $50.26 \pm 12.48(45-60)$ \\
\hline Use of cardiopulmonary bypass & $63(75 \%)$ \\
\hline Hospital death & $9(10.7 \%)$ \\
\hline Late death & $2(2.7 \%)$ \\
\hline Lost to follow-up & $1(1.4 \%)$ \\
\hline Number of patients followed-up & $72(98.6 \%)$ \\
\hline
\end{tabular}

Table 1: Demographics of the patients in the study population $(n=84)$ 


\begin{tabular}{|c|c|c|c|c|}
\hline S.No. & $\begin{array}{c}\text { Number } \\
\text { of } \\
\text { patients }\end{array}$ & Age at operation & Diagnosis & Operation \\
\hline 1. & 5 & $\begin{array}{l}9 \text { months, } 10 \text { months, } 10 \\
\text { months, } 10 \text { months, } 12 \text { months }\end{array}$ & Symptomatic tetralogy of Fallot & Intracardiac repair \\
\hline 2. & 2 & 9 months, 10 months & Tetralogy of Fallot, absent pulmonary valve & Intracardiac repair \\
\hline 3. & 9 & $\begin{array}{l}2 \text { months, } 3 \text { months, } 3 \frac{1 / 2}{2} \\
\text { months, } 4 \text { months, } 4 \text { months, } 6 \\
\text { months, } 8 \text { months, } 8 \text { months, } 8 \\
\text { months }\end{array}$ & $\begin{array}{l}\text { Tetralogy of Fallot with pulmonary stenosis/hypoplastic } \\
\text { pulmonary arteries/atresia, univentricular heart with } \\
\text { pulmonary stenosis/atresia, atrioventricular septal defect with } \\
\text { pulmonary atresia }\end{array}$ & $\begin{array}{l}\text { Right-sided modified } \\
\text { Blalock-Taussig's } \\
\text { shunt/UKC shunt }\end{array}$ \\
\hline 4. & 1 & 5 months & Severe pulmonary stenosis with atrial septal defect & $\begin{array}{l}\text { Pulmonary valvotomy } \\
\text { and atrial septal defect } \\
\text { closure (patch) }\end{array}$ \\
\hline 5. & 8 & $\begin{array}{l}1 \text { month, } 1 \text { month, } 2 \text { months, } 2 \\
\text { months, } 2 \text { months } 1 \text { month, } 4 \\
\text { months, } 1 \text { month }\end{array}$ & $\begin{array}{l}\text { Tricuspid atresia/univentricular heart, multiple ventricular } \\
\text { septal defect/unbalanced atrioventricular septal defect with } \\
\text { increased pulmonary blood flow, failure to thrive, on } \\
\text { preoperative ventilation }\end{array}$ & $\begin{array}{l}\text { Pulmonary artery } \\
\text { banding }\end{array}$ \\
\hline 6. & 4 & $\begin{array}{l}9 \text { months, } 10 \text { months, } 11 \\
\text { months, } 11 \text { months }\end{array}$ & Tricuspid atresia/univentricular heart with pulmonary stenosis & $\begin{array}{l}\text { Bidirectional Glenn with } \\
\text { anterior flow open }\end{array}$ \\
\hline 7. & 3 & $\begin{array}{l}10 \text { months, } 11 \text { months, } 11 \\
\text { months }\end{array}$ & $\begin{array}{l}\text { Univentricular heart with excessive pulmonary blood flow } \\
\text { operation }\end{array}$ & $\begin{array}{l}\text { Bidirectional Glenn with } \\
\text { pulmonary artery } \\
\text { banding }\end{array}$ \\
\hline 8. & 9 & $\begin{array}{l}20 \text { days, } 20 \text { days, } 12 \text { days, } 19 \\
\text { days, } 20 \text { days, } 1 \text { month, } 18 \\
\text { days, } 19 \text { days, } 2 \text { months }\end{array}$ & Transposition of the great arteries & Arterial switch operation \\
\hline 9. & 2 & 3 months, 5 months & Transposition of the great arteries (late presentation) & Senning's operation \\
\hline 10. & 1 & 2 months & Aortopulmonary window & Johanson's repair \\
\hline 11. & 2 & 2 months, 5 months & $\begin{array}{l}\text { Anomalous origin of left coronary artery from pulmonary } \\
\text { artery }\end{array}$ & Anatomical restoration \\
\hline 12. & 7 & $\begin{array}{l}31 / 2 \text { months, } 4 \text { months, } 6 \\
\text { months, } 8 \text { months, } 8 \text { months, } \\
10 \text { months, } 11 \text { months }\end{array}$ & $\begin{array}{l}\text { Ventricular septal defect (multiple ventricular septal } \\
\text { defect/prematurity/ preoperative ventilation/malnutrition) }\end{array}$ & $\begin{array}{l}\text { Ventricular septal defect } \\
\text { closure }\end{array}$ \\
\hline 13. & 2 & 1 month, 1 month & Coarctation of aorta with patent ductus arteriosus & $\begin{array}{l}\text { Resection and end-to- } \\
\text { end anastomosis, } \\
\text { division of patent ductus } \\
\text { arteriosus }\end{array}$ \\
\hline 14. & 3 & 30 days, 35 days, 20 days & $\begin{array}{l}\text { Coarctation of aorta with ventricular septal defect on } \\
\text { ventilator }(2 \mathrm{~kg}, 2.5 \mathrm{~kg})\end{array}$ & $\begin{array}{l}\text { Pulmonary artery } \\
\text { banding, repair of } \\
\text { coarctation }\end{array}$ \\
\hline 15. & 1 & 2 months & Interrupted aortic arch & Restoration of aorta \\
\hline 16. & 2 & 9 months, 11 months & $\begin{array}{l}\text { Previous pulmonary artery band due to multiple muscular } \\
\text { ventricular septal defects }\end{array}$ & $\begin{array}{l}\text { Debanding pulmonary } \\
\text { artery, VSD closure, } \\
\text { pulmonary arterioplasty }\end{array}$ \\
\hline 17. & 2 & 2 months, 3 months & Atrioventricular septal defect & Two-patch repair \\
\hline 18. & 3 & 3 months, 5 months, 6 months & $\begin{array}{l}\text { Heterotaxy with univentricular heart, pulmonary stenosis, } \\
\text { decreased pulmonary blood flow }\end{array}$ & Bidirectional Glenn \\
\hline 19. & 3 & 20 days, 1 month, 1 month & $\begin{array}{l}\text { Heterotaxy with totally anomalous pulmonary venous } \\
\text { connection }\end{array}$ & $\begin{array}{l}\text { Rechanneling of totally } \\
\text { anomalous pulmonary } \\
\text { venous connection }\end{array}$ \\
\hline 20. & 3 & 5 days, 15 days, 7 days & $\begin{array}{l}\text { Totally anomalous pulmonary venous connection } \\
\text { (infracardiac) on preoperative ventilator }\end{array}$ & $\begin{array}{l}\text { Rechanneling of totally } \\
\text { anomalous pulmonary } \\
\text { venous connection }\end{array}$ \\
\hline 21. & 8 & $\begin{array}{l}39 \text { days, } 2 \text { months, } 2 \text { months, } 3 \\
\text { months, } 3 \text { months, } 3 \text { months, } 5 \\
\text { months, } 9 \text { months }\end{array}$ & $\begin{array}{l}\text { Totally anomalous pulmonary venous connection } \\
\text { (supracardiac) }\end{array}$ & $\begin{array}{l}\text { Rechanneling of totally } \\
\text { anomalous pulmonary } \\
\text { venous connection }\end{array}$ \\
\hline 22. & 4 & $\begin{array}{l}1 \text { month, } 2 \text { months, } 2 \text { months, } 1 \\
\text { month }\end{array}$ & Mixed totally anomalous pulmonary venous connection & $\begin{array}{l}\text { Rechanneling of totally } \\
\text { anomalous pulmonary } \\
\text { venous connection }\end{array}$ \\
\hline
\end{tabular}

Table 2: Age at primary operation, diagnosis, type of operation of all patients in the study group undergoing tracheostomy $(\mathrm{n}=84)$ 
Twenty-nine (34.5\%) patients required preoperative ventilation. A combination of three or more risk factors requiring prolonged mechanical ventilation were present in $58.3 \%(n=49)$ patients (Table 3).

\begin{tabular}{|c|c|}
\hline Postoperative issues & No. $(\%)$ \\
\hline Cardiac (Congestive heart failure, poor biventricular function, unstable hemodynamics) & $35(41.66)$ \\
\hline Cardiac cachexia, low body mass, malnourishment, unstable hemodynamics & $39(46.4)$ \\
\hline Persistent lobar collapse, pulmonary infection, sepsis & $19(22.6)$ \\
\hline Severe pulmonary artery hypertension (cardiac related) & $39(46.4)$ \\
\hline Renal failure requiring peritoneal dialysis & $17(20.2)$ \\
\hline Unilateral diaphragmatic paralysis & $6(7.1)$ \\
\hline Preoperative neurological event (Hypoxic, hydrocephalus) & $5(5.9)$ \\
\hline $\begin{array}{l}\text { Postoperative new onset neurological event (Hypoxic, intracerebral bleed, subdural } \\
\text { hematoma) }\end{array}$ & $6(7.1)$ \\
\hline Craniofacial syndromes and upper airway problems, glossoptosis & $16(19)$ \\
\hline Excessive pulmonary secretions & $37(44)$ \\
\hline Chylothorax requiring surgical intervention & $4(4.7)$ \\
\hline Postoperative extracorporeal membrane oxygenation & $3(3.6)$ \\
\hline Subglottic stenosis & $3(3.6)$ \\
\hline Tracheobronchomalacia & $3(3.6)$ \\
\hline Cardiac + Renal & $36(42.8)$ \\
\hline Cardiac and subglottic stenosis & $13(15.5)$ \\
\hline Cardiac + Tracheobronchomalacia + suprastomal collapse & $13(15.5)$ \\
\hline Cardiac + Diaphragmatic paralysis & $14(16.6)$ \\
\hline Cardiac + Neurological event & $30(35.7)$ \\
\hline 3 or more of $(1-11)$ & $49(58.3)$ \\
\hline
\end{tabular}

Table 3: Reasons for prolonged ventilation of all patients in the study group undergoing tracheostomy $(n=84)$

Ventilation could not be weaned sufficiently to allow a trial of extubation in $39(46.4 \%)$ patients. In $38(45.2 \%)$ cases extubation had failed on single occasion, and in $7(8.3 \%)$ cases on two occasions.

Among original cohort of 84 patients, there were 9 (10.8\%) perioperative deaths after tracheostomy while still ventilated through the tracheostomy within 30 post-operative days due to a combination of 3 or more risk factors. There were 2(2.7\%) late deaths 39 and 81 months after surgery due to renal failure $(n=1)$, and cerebral thrombosis $(n=1)$ respectively. One patient was lost to follow-up.

\section{Cohort of survivors}

One infant with tracheobronchomalacia had local infection at the tracheostomy site and the tracheostomy was exchanged for a period of nasotracheal ventilation. After controlling the infection, the tracheostomy wound was revised without additional complications. Two children with subglottic stenosis who were preoperatively ventilated for 15 and 20 days respectively underwent excision of subglottic membrane and cricoid splinting and were ventilated for a period of 3 weeks in two sessions. There were no other tracheostomy-related complications.

Preoperative ventilation before the "primary operation", pulmonary infection, subglottic stenosis, tracheobronchomalacia, diaphragmatic 
paralysis, cardiac cachexia, renal failure, and sepsis were associated with a longer period of post tracheostomy ventilation.

Decannulation was successful in all 72 infants. All neonates and infants received dual source of oxygenation (transtracheostomy) and nasal prongs or oxygen hood) for a period between 1-5 days. There were no instances of hypoxic adverse events. A patent stoma allowed intermittent endotracheal suction and nutrition was attended to during this critical period through nasogastric feeling. Temporary stomal manipulation / instrumentation for 1-5 days did not affect stomal healing and there were no post decannulation complications.

The median duration of mechanical ventilation after tracheostomy was 22 days (range 11-35 days) and the median duration of tracheostomy to decannulation in survivors was 31 days (30-52 days). Sixty-eight (94.4\%) survivors were in Ross's clinical score of 2 and without antifailure cardiac medications. There was no reoperation following decannulation. At the end of the follow-up, all survivors were successfully decannulated.

\section{Comment}

Tracheostomy is performed in $1.3 \%$ to $2.7 \%$ of children following cardiac surgery due to the requirement of prolonged ventilation and various other reasons. [1-3] The predisposing factors include younger age, prematurity, low birth weight, cardiac cachexia, preoperative mechanical ventilation, longer CPB time, premature extubation, the need for reoperation, phrenic nerve injury, diaphragmatic paralysis and sepsis. [1-7]

Tracheostomy has been shown to reduce total mechanical ventilation time, decrease the occurrence of lower respiratory tract infection, improve oral and dental hygiene, reduce upper airway injury including vocal cord ulceration, reduce in-hospital mortality and hospital cost. [810]Additionally, it decreases the number of self extubations, requirement of sedation, decrease dead space ventilation, airway resistance and work of breathing, allows weight gain through enteral/parenteral feeds, thereby facilitating separation from ventilator support, shorten ICU and hospital stays. [8-10]

There is no consensus in the published literature on the indications, and timing of pediatric tracheostomy and on the optimal decannulation protocol. Data from the pediatric population are limited to small, singlecenter reviews, and it is indeed difficult to extrapolate data from other centers. [6,7]. Additionally, in the developing world, there is a high incidence of post-operative sepsis.

Children requiring tracheostomy after surgery for CHD are at significant risk or poor outcomes with less than half still alive at a median follow-up of 3.9 years. [1-3] Mastropietro reported an overall mortality rate of $25.2 \%$ among 606 tracheostomies in neonates and infants in the STS congenital Heart Surgery database. [1] Johnson and colleagues in a multi institutional study reported an overall mortality rate of $21.6 \%$ on 1292 pediatric tracheostomies. [2] Our overall mortality rate of $10 \%$ is in accordance with the published investigations which documents a tracheostomy- related mortality between $3.2 \%$ and $25 \%$ after 1985. [1-10]

Both anatomic and physiologic characteristics of the infant trachea require special surgical techniques and adequate postoperative care. Infants have shorter and fatter necks than adults. The infant larynx is situated more superior and anterior in the neck at the level of the third or fourth cervical vertebra, and it starts to descend at around 2 years of age. Its size is approximately $1 / 3^{\text {rd }}$ that of the adult larynx. The hyoid frequently overlies the thyroid cartilage notch, making palpation of the anatomic landmarks difficult. The infant thyrohyoid membrane is also much shorter. The cricoid cartilage is the narrowest part of the airway in a child, and in adults, it is vocal cords.
If a tracheostomy is being planned for upper airway obstruction due to subglottic stenosis or complete tracheal rings, tracheostomy may be difficult, with risk of damage to the posterior tracheal wall. Although debatable, a midline vertical incision in infants through the $2^{\text {nd }}$ or $4^{\text {th }}$ tracheal cartilages is the most preferred technique.

The important issues which require consideration while performing pediatric tracheostomy are: i) the underlying indication of tracheostomy incision, ii) prevention of accidental decanulation; iii) avoidance of suturing the tracheostomy tube to the skin; and iv) prevention of longterm tracheal stenosis.

Following placement of the tracheostomy tube, one of the concerns is the duration of time that the patients remain dependent on the device. In our study, we have been able to decannulate all infants prior to discharge. Due to lack of health care resources, hospital discharge with a tracheostomy or ventilator is not a viable option in India, therefore in hospital decannulation is preferable in our setup.

Stomaplasty techniques introduced by Eliachar, Koltai, and Bjork involves the resection of the tracheal cartilages and are recommended when longer duration of tracheostomy is expected. ${ }^{1-4} \mathrm{We}$ did not use any of these methods, since we expected our patients to be decannulated before discharge.

The reported incidence of pediatric tracheostomy-related complications is around $15 \%-19 \% \cdot[1-10]$ In this study, there was one case of tracheitis and two patients had sub glottic stenosis. In order to avert decannulation failure in these compromised neonates and infants, we developed this technique of dual source oxygenation following decannulation. Thus, there were five forces driving our decision-making for technical modifications to facilitate decannulation of the tracheostomy tube;

- $\quad$ the desire to maintain uninterrupted oxygenation for a varying period between 1-5 days;

- maintain dual source of sustained oxygenation(trans tracheostomy and oxygen hood );

- avert decannulation failure and hypoxic adverse events in neonates and infants with cardiac cachexia and acyanotic/cyanotic CHD with or without pulmonary hypertension;

- maintain feeding through nasogastric tube(which keeps one nostril blocked) during the post decannulation period;

- $\quad$ perform endotracheal suction through the tracheostomy stoma until peristomal edema subsided and natural non obstructive airway is restored;

We have been able to address all our desires by this technique presented herein and we conclude that this technical modification is simple, reproducible, and inexpensive, allows sustained oxygenation, thus averts decannulation failure and hypoxic post decannulation adverse events.

\section{Study Limitations}

Since we have achieved step one-demonstration of safety, a comparative trial of conventional decannulation and "dual-source" oxygenation following decannulation is the topic of our future investigation.

\section{Conclusions}

We conclude that transtracheal oxygenation via a thin silastic catheter in neonates and infants undergoing decannulation of tracheostomy tube provides uninterrupted route of oxygenation, allows continuation of enteral feeds, facilitates intermittent endotracheal suction until peristomal oedema subsides and natural non-obstructive airway is restored. 
This "dual-source" strategy of oxygen administration is safe, expedient and obviates the need to remove the nasogastric tube for oxygen administration via nasal cannula. Knowledge of this approach should contribute to the armamentarium of cardiac surgeons faced with decannulation of the tracheostomy tube.

\section{References}

1. Mastropietro $\mathrm{CW}$, Benneyworth $\mathrm{BD}$, Turrentine $\mathrm{M}$ et al. Tracheostomy after operations for congenital heart disease: an analysis of the Society of Thoracic Surgeons congenital heart surgery database. Ann Thorac Surg 2016; 101:2285-2292.

2. Johnson JT, Marino BS, Klugman D, Shamszad P. National variation in the use of tracheostomy in patients with congenital heart disease. Pediatr Crit Care Med 2017; 18(10): 958-64 (DOI: 10.1097/PCC.0000000000001286)

3. Cotts T, Hirsch J, Thorne M, Gajarski R. Tracheostomy after pediatric cardiac surgery: frequency, indications, and outcomes. J Thorac Cardiovasc Surg. 2011;141 (2):413-418.

4. Curtis JJ, Clark NC, McKenney CA, et al. Tracheostomy: a risk factor for mediastinitis after cardiac operation. Ann Thorac Surg. 2001;72 (3):731-734.
5. Stamenkovic SA, Morgan IS, Pontefract DR, Campanella C. Is early tracheostomy safe in cardiac patients with median sternotomy incisions? Ann Thorac Surg. 2000; 69(4): 11521154.

6. Shlugman D, Satya-Krishna R, Loh L. Acute fatal haemorrhage during percutaneous dilatational tracheostomy. Br J Anaesth 2003; 90(4): 517-520.

7. Leung R, Berkowitz RG. Decannulation and outcome following pediatric tracheostomy. Ann Otol Rhinol Laryngol 2005;114(10): 743-748.

8. Benjamin B. Prolonged intubation injuries of the larynx: endoscopic diagnosis, classification, and treatment. Ann Otol Rhinol Laryngol Suppl. 1993; 160: 1-15.

9. Nicklaus PJ, Crysdale WS, Conley S, White AK, Sendi K, Forte V. Evaluation of neonatal subglottic stenosis: a 3-year prospective study. Laryngoscope. 1990; 100: 1185-1190.

10. Santos PM, Afrassiabi A, Weymuller EA Jr. Risk factors associated with prolonged intubation and laryngeal injury. Otolaryngol Head Neck Surg. 1994; 111: 453-459.
This work is licensed under Creative Commons Attribution 4.0 License

To Submit Your Article Click Here: Submit Article

DOI: $10.31579 / 2641-0419 / 085$
Ready to submit your research? Choose Auctores and benefit from:

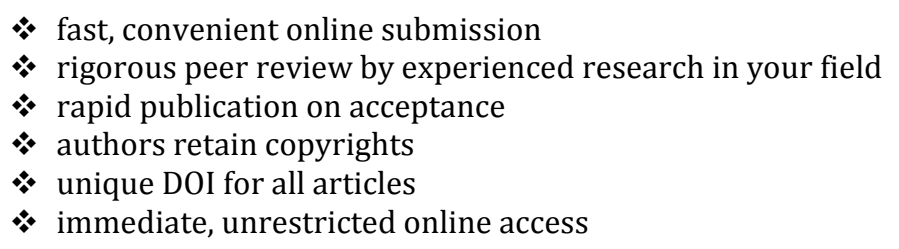

At Auctores, research is always in progress.

Learn more www.auctoresonline.org/journals/clinical-cardiology-andcardiovascular-interventions 